Л.В. Квік,

аспірантка кафедри релігієзнавства, теології і культурологї ДВНЗ «ПНУ імені Василя Стефаника»

\title{
ЗАСАДНИЧІ ЧИННИКИ СУСПІЛЬНОГО МИРУ У ВЧЕННІ ПАПИ БЕНЕДИКТА ХVI
}

Сьогоднішнє глобалізоване суспільство відзначається колосальним науковим, технічним та економічним прогресом. XXI століття - це час великих, надзвичайно актуальних викликів, які стоять перед людством. Одним із них є проблема суспільного миру, оскільки характерними є триваючі війни та прояви агресії як між країнами, так і в середині них. Наслідками таких явищ є відсутність миру і порозуміння в суспільстві, на рівні держави та, що ще гірше, відсутність мирного співжиття між народами, а інколи і в них самих. Тому проблема подолання постійних воєнних конфліктів та агресії у світі та досягнення миру постає нагальною в нашому суспільному житті і є актуальним предметом дослідження. Вона є предметом дослідження багатьох галузей гуманітарних наук, зокрема соціології та релігієзнавства. Дослідженням даної проблеми займалися такі вчені, як М.Бабій [1], Т.Дзядевич [8], Д.Марціновська [6], В.Бондаренко [2] та ін.

Метою нашого дослідження є виокремлення основних чинників суспільного миру в ученні папи Бенедикта XVI, який приділяв значну увагу вирішенню названих проблем.

Відсутність миру він трактував як найважливіший чинник, який заважає повноцінно жити та розвиватися людині та суспільству загалом. У своєму вченні про суспільний мир папа повністю солідарний 3 декларацією Другого Ватиканського собору «Dignitatis Humanae» («Гідність людська» (1965 р.) і засадничими чинниками суспільного миру називає людську гідність та релігійну свободу. Цей Ватиканський собор сформулював належні відповіді на сучасні суспільні та культурні виклики $[6,2]$, серед яких - відсутність сталого мирного життя.

Спробуємо виокремити засадничі чинники суспільного миру; проаналізувати їхній стан на сьогоднішній день; висвітлити основні шляхи досягнення суспільного миру, запропоновані папою Бенедиктом XVI.

У сьогоднішньому секуляризованому суспільстві людська гідність 
дуже часто придушується і нівелюється. Дедалі частіше можемо спостерігати те, що в деяких регіонах світу ще досі неможливо вільно сповідувати свою віру, в інших - панують інколи приховані форми пересудів та опозиції проти віруючих і релігійних символів, незважаючи на те, що релігійна віра $є$ феноменом духовно-суспільним і має реалізуватися на суспільному рівні $[6,1]$.

У США один із найбільш авторитетних центрів вивчення суспільної думки, «Pew Forum», у своїй публікації від 14 січня 2014 р., відзначив зростання у світі дискримінації на релігійному грунті. 3'ясовано, що майже 3/4 (74\%) людей світу проживають у країнах 3 високим рівнем дискримінації із релігійним підгрунтям. У рапорті «Pew Forum» йдеться також про нападки на релігію як з боку соціуму, так і з боку певних держав.

Дослідницький центр виділяє такі найважливіші причини значного зростання утисків релігійної свободи, як дискримінація релігійних меншин (у 47\% досліджених країн); насильство й погрози, метою яких є примушування поводитися відповідно до певних норм (39\%); насильство і покарання, накладені на жінок за невідповідний одяг (32\%); злочини на релігійному тлі $(25 \%)$ та тероризм, проголошений в ім'я релігії (20\%). Всі ці утиски релігійної свободи грубо порушують та зневажають людську гідність [10].

У «Загальній декларації прав людини» з 1948 р. наголошується на тому, що кожна людина має право на визнання своєї гідності, а також на визнання рівних та невід'ємних прав, які $є$ основою свободи, справедливості та загального миру. Вже у першій статті Декларації йде мова про те, що всі люди народжуються вільними і рівними у своїй гідності та правах. У вісімнадцятій статті чітко окреслюється право кожної людини на релігійну свободу: «Кожна людина має право на свободу думки, совісті і релігії; це право включає свободу змінювати свою релігію або переконання і свободу сповідувати свою релігію або переконання як одноособово, так і разом з іншими, прилюдним або приватним порядком в навчанні, богослужінні та виконанні релігійних та ритуальних обрядів» [7].

Оскільки в світі дедалі частіше мають місце релігійні утиски, переслідування, зазіхання на релігійну свободу та моральне і фізичне насильство, то як наслідок суспільство стає більш агресивним, озлобленим та егоїстичним. Такі стрімкі тенденції до руйнування гармонійного співіснування людства спричинюють втрату миру, масштабні порушення прав людини та наругу над людською гідністю. 
Католицька Церква в прийнятій на II Ватиканському Соборі декларації про релігійну свободу «Dignitatis Humanae» теологічно обгрунтувала право на свободу релігії і практично підтримала закріплені в світській системі людських прав принципи свободи совісті та свободи віросповідання $[4,257]$. У цій царині ніхто не повинен чинити проти власної совісті, обов'язку й відповідальності. Має бути забезпечена свобода здобування релігійної освіти та релігійної інформації [1, 125-126].

Названий документ становить важливу віху в розумінні концепції свободи релігії. Ця концепція полягає в тому, що «кожна людина має бути вільною від приневолення як з боку окремих осіб чи суспільних груп, так і з боку будь-якої людської влади, щоб нікого не силували діяти всупереч власному сумлінню і нікому не перешкоджали діяти згідно з власними переконаннями в релігійних справах - приватно чи прилюдно, поодинці чи спільно з іншими в належних межах» [4, 254]. I тут же йдеться про те, що право на релігійну свободу грунтується саме на людській гідності, яку людина здатна досвідчити через Слово Боже, і через свій розум. Це право випливає саме з людської гідності, чию трансцендентну природу не можна ігнорувати і не бачити. І це є священним правом людини на життя фізичне і на життя духовне. Наука про людську гідність і свободу, яка випливає з неї, закорінена у Божому Об'явленні, яке розкриває гідність людини в усіх вимірах. Боже Об'явлення показує нам повагу Ісуса Христа до свободи людини через дарування їй вільної волі. Підтвердження того, що людська гідність $є$ найвищою цінністю, можемо знайти у Святому Письмі, в «Книзі Псалмів»: «Коли я погляну на небо - діло рук Твоїх, на місяць і зорі, які Ти заснував, - хто така людина, що пам'ятаєш про неї, або людський син, що навідуєшся до нього? Ти зробив іiі дещо меншою за ангелів, Ти увінчав іiі славою і честю. I поставив Ти його над ділами рук Своїх, усе підкорив йому під ноги» (Пс. 8: 4-7).

На проблемі трансцендентної гідності людини наголошує i Святіший Отець, оскільки ця характеристика є найбільшою цінністю, яку, завдяки можливостям людини мислити, може пізнати кожен. Гідність людської особи понтифік розуміє як здатність піднестися над власним матеріальним буттям і здатність до пошуку правди. Папа підкреслює, що людську гідність варто визнати універсальним благом, без якого $є$ неможливою побудова суспільства, спрямованого на якнайповнішу реалізацію людського потенціалу, адже «повага 
до найсуттєвіших елементів людської гідності, таких як право на життя й право на релігійну свободу, - це передумова моральної легітимності будь-яких соціальних чи правових норм» [9].

Разом $з$ тим папа Бенедикт XVI в енцикліці «Любов у правді» зауважує, що в сучасному світі має місце прикра тенденція, а саме заперечення права на релігійну свободу та зазіхання на людську гідність. При цьому він має на увазі не тільки війни та конфлікти, які спалахують у світі на релігійному підгрунті, але й насильницькі діï, що гальмують справжній розвиток суспільства і перешкоджають просуванню народів до значного духовного та соціально-економічного благополуччя [3, 37].

У своїй відомій книзі «Віра, істина і толерантність» папа Бенедикт XVI, проаналізувавши взаємозв'язок істини і свободи, підсумував, що заперечення Бога ліквідує основи людської гідності та iii свободи [5, 352]. Всі люди, відповідно до своєї гідності і до власної природи, спонукувані шукати правду, насамперед ту, що стосується релігії. Адже особа прагне до істини, оскільки це випливає 3 того, що людина обдарована розумом і вільною волею [3, 254]. Тому саме істина про Бога і людину робить іï справді вільною, а відтак людині необхідно прагнути до пізнання Бога. Саме тому неприпустимими є утиски релігійної свободи, на чому наголошує папа: «Якщо немає істинності людини, то вона не є свобідною. Тільки істина робить нас вільними» [5, 352]. Цей висновок папи кореспондується $з$ декларацією «Dignitatis Humanae», котра наголошує, що пошук цієї істини має здійснюватися у відповідний для гідності людської особи спосіб [3, 255].

16 грудня 2010 року у Ватикані було представлено послання папи Бенедикта XVI з нагоди XLIV Всесвітнього дня миру, темою якого було: «Релігійна свобода - шлях до миру». У ньому папа наголосив на необхідності релігійної свободи в усьому світі як передумови побудови миру. Мир, за його словами, - це праця людського сумління, яке відкривається до істини та любові. Він підкреслив, що «релігійна свобода - це привілейований спосіб побудови миру в світі» [9].

У посланні понтифік звертає увагу на те, що сьогодні велика кількість християн щоденно потерпають від постійних образ і часто мусять жити в страху через своє прагнення до пізнання істини, віру в Ісуса Христа та заклики до світу шанувати релігійну свободу. Папа підкреслює, що така ситуація не може тривати й надалі, бо є виявом 
зневаги до Бога й людської гідності. Вона також виступає загрозою для суспільного миру та безпеки і $є$ вагомою перешкодою на шляху до всебічного та правдивого людського розвитку. На думку папи Бенедикта XVI, обмеження релігійної свободи спричинює значне применшення розуміння людської особи, а применшувати громадську роль релігії у суспільстві - означає нехтувати справжньою природою людини, наслідком чого $є$ унеможливлення настання правдивого й тривалого миру [9].

За словами папи, першим вихователем прагнення до свободи i миру є сім'я. І оскільки релігійна свобода - це шлях до миру, то саме релігійна освіта $є$ найкращим способом навчити нові покоління бачити в іншому ближнього, з яким люди повинні іти вперед задля того, щоб усі люди були членами мирного суспільства [9].

Папа стверджує, що серед фундаментальних прав та свобод, які грунтуються на гідності людської особи, особливий статус має релігійна свобода. I саме намагання завадити людям вільно сповідувати власну віру є зазіханням на людську гідність, наслідком якого $є$ загроза справедливості й миру в суспільстві. Якщо в державі панує здорова політична та правова культура, то релігійна свобода завжди буде іï плодом і великим благом. Бенедикт XVI підкреслює, що релігійні права належать до сутнісного ядра природних прав людини і державне право в жодному разі не може заперечувати їх. Релігійна свобода - «це істотний елемент конституційного ладу в державі; заперечення релігійної свободи - це водночас і замах на всі фундаментальні права й свободи, бо ж релігійна свобода - це їх синтез і вершина. Це, можна сказати, лакмусовий папірець поваги до всіх інших прав людини» [9].

Ще однією особливістю релігійної свободи є її публічний вимір. I хоча вона бере свій початок в особистісній сфері, проте реалізується в стосунках з іншими людьми. Понтифік наголошує на тому, що державна влада має бути відокремлена від релігійного життя і не повинна втручатися в релігійний розвиток своїх громадян. При цьому він посилається на слова декларації «Dignitatis Humanae»: «Державній владі не можна силою, залякуванням чи іншим чином накидати громадянам визнавання чи заперечення якої-небудь релігії або перешкоджати тому, щоб хтось вступав до релігійної спільноти чи залишав їі» [4, 258].

Ще раз підкреслюючи, що релігійна свобода - прямий шлях до суспільного миру, папа каже, що світ гостро потребує Бога, а 
також універсальних, моральних та духовних цінностей і що саме релігія може допомогти в їх пошуку задля побудови мирного й справедливого суспільства. «Мир - це дар Божий, а водночас і завдання для людства, мета, яка ніколи не буде остаточно досягнута» [9]. Понтифік переконаний у тому, що ближчим до миру є те суспільство, яке примирилося з Богом, адже «мир - це не просто відсутність війни, не просто результат мілітарного або економічного домінування, а тим паче - обманних ходів чи хитрої маніпуляції. Мир - це результат процесу очищення і культурного, морального та духовного розвитку кожної людини й кожного народу, в якому сповна шанується людська гідність» [9].

Відтак, релігійна свобода, яка випливає 3 гідності людської особи, виступає засадничим чинником суспільного миру, оскільки $\epsilon$ фундаментальним правом людської особи. Саме вона $є$ тим чинником, який покликаний консолідувати увесь світ. Досягнувши іï, людство зможе мирно співіснувати і гармонійно розвиватися. Як наголошує Бенедикт XVI, релігійна свобода є істотним елементом конституційного ладу в державі і саме ії заперечення $є$ посяганням на всі фундаментальні права й свободи людини, які мають за свою основу людську гідність, право на яку дане людині Богом та закріплене у «Загальній декларації прав людини» 1948 року. Святіший Отець закликав усіх людей доброї волі розбудовувати такий новий світ, у якому кожен зможе вільно сповідувати свою віру та вільно виявляти свою належність до певної релігії, вповні здійснювати всі свої фундаментальні права. Його фундаментальний висновок поглядає в тому, що суспільство повинне усвідомити - всі блага релігійної свободи відкривають прямий шлях до миру.

Перспективи подальших досліджень полягають у продовженні вивчення віронавчальної спадщини папи Бенедикта XVI під кутом зору пошуку відповідей на релігійно-суспільні виклики сучасності.

\section{ЛІТЕРАТУРА}

1. Бабій М.Ю. Свобода совісті та свобода релігії: концептуальна матриця Католицької Церкви // Юридична наука. - 2013. - №3. - С. 118-128.

2. Бондаренко В.Д. Релігія і політика // Релігійна свобода: наук. зб. - К., 1998. - C. 28-36.

3. Венедикт XVI. Енцикліка «Любов у правді». - Жовква, 2010. - 128 с. 
4. Документи Другого Ватиканського Собору (1962-1965): Конституції, декрети, декларації. Коментарі; пер. 3 лат. / Український католицький університет. - Львів, 2014. - 608 с.

5. Ратциигер Й. Вера - Истина - Толерантность. Христианство и мировые религии. - М., 2007. - 367 с.

6. Мариіновська Д.С. Феномен релігійної віри в католицизмі: проблемні дискурси XX - початку XXI століть: автореф. дис. на здобуття наук. ступеня канд. філос. наук: спец. 09.00.11 «Релігієзнавство». - К., 2013. - 20 с.

7. Всеобщая декларация прав человека Принята и провозглашена в резолюции 217 А (III) Генеральной Ассамблеи от 10 декабря 1948 года. [Електронний pecypc]. - Режим доступу: http://zakon1.rada.gov.ua/laws/show/995_015

8. Дзядевич Т. Відповідальна свобода. [Електронний ресурс] / Тетяна Дзядевич. - Режим доступу: http://katolyckyj-visnyk.blogspot.com/2013/01/blogpost_5112.html

9. Послання його святості Папи Венедикта XVI з нагоди Всесвітнього дня миру. [Електронний ресурс]. - Режим доступу: http://osbm-kyiv.com.ua/ poslannya-joho-svyatosti-papy-venedykta-hvi-z-nahody-vsesvitnoho-dnya-myru/

10. Na świecie wzrasta wrogość wobec religio. [Електронний ресурc]. - Peжим доступу: http://www.deon.pl/religia/kosciol-i-swiat/z-zycia-kosciola/ art,17246,na-swiecie-wzrasta-wrogosc-wobec-religii0.html

Квік Л.В. Засадничі чинники суспільного миру у вченні папи Бенедикта ХИ.

У статті порушуються актуальні проблеми сьогодення, а саме відсутність стабільного миру в світі та зазіхання на основні права людини. Мета - дослідження засадничих чинників миру в світі XXI ст. у вченні папи Бенедикта XVI та аналіз запропонованих ним шляхів досягнення суспільного миру. Автор розглядає сучасний стан релігійної свободи у світі та аналізує взаємозв'язок між людською гідністю і релігійною свободою, які є одними з основних прав людини.

Ключові слова: папа Бенедикт XVI, суспільний мир, гідність людини, релігійна свобода.

Квик Л.В. Основные факторы общественного мира в учениях папы Бенедикта XVI.

В статье поднимаются актуальные проблемы современности, а именно отсутствие стабильного мира в мире и посягательства на основные права человека. Цель - исследование основных факторов мира в мире XXI века в учении папы Бенедикта XVI и анализ предложенных им путей достижения общественного мира. Автор рассматривает современное состояние религиозной свободы в мире и анализирует взаимосвязь между человеческим достоинством и религиозной свободой, которые являются одними из основных прав человека. 
Ключевые слова: папа Бенедикт XVI, общественный мир, достоинство человека, религиозная свобода.

Kvik L. Fundamental factors of social peace in the doctrine of Pope Benedict XVI.

The article violated urgent problems of our time, namely the absence of a stable peace in the world and infringement on basic human rights that et guarantees the Universal Declaration of Human Rights of 1948, especially the right to dignity of the human person and the right to religious freedom. The purpose of this article is to distinguish and study the mail factors of achievement peace in the world of the XXI century in the doctrine of Pope Benedict XVI and analysis of him proposed ways of achieving social peace. The author examines the modern situation of religious freedom in the world and reveals the negativ econsequences of its repression. And analyzed the relationship between human dignity and religious freedom, which is one of the fundamental human rights. freedom.

Key words: Pope Benedict XVI, social peace, human dignity, religious 